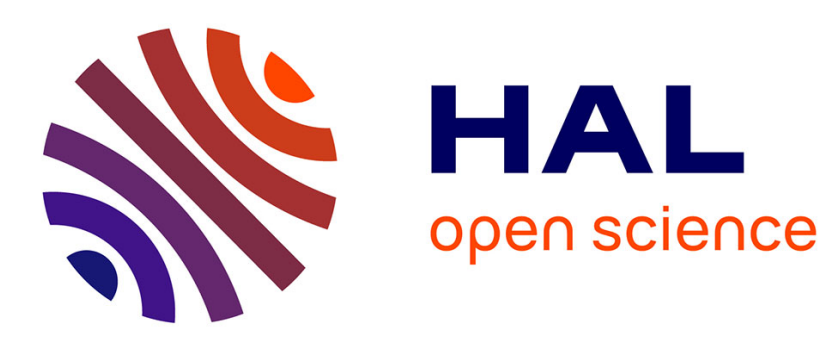

\title{
Health outcomes resulting from the quality of emotional expression in HIV/AIDS patients
}

Nicole Cantisano, Bernard Rimé, Mohammad Afzali, María Muñoz-Sastre

\section{To cite this version:}

Nicole Cantisano, Bernard Rimé, Mohammad Afzali, María Muñoz-Sastre. Health outcomes resulting from the quality of emotional expression in HIV/AIDS patients. European Review of Applied Psychology / Revue Européenne de Psychologie Appliquée, 2016, 66 (3), pp.95-100. 10.1016/j.erap.2016.04.009 . hal-02482249

\section{HAL Id: hal-02482249 \\ https://hal-univ-tlse2.archives-ouvertes.fr/hal-02482249}

Submitted on 29 Apr 2020

HAL is a multi-disciplinary open access archive for the deposit and dissemination of scientific research documents, whether they are published or not. The documents may come from teaching and research institutions in France or abroad, or from public or private research centers.
L'archive ouverte pluridisciplinaire HAL, est destinée au dépôt et à la diffusion de documents scientifiques de niveau recherche, publiés ou non, émanant des établissements d'enseignement et de recherche français ou étrangers, des laboratoires publics ou privés. 


\title{
QUALITY OF SSE AND HEALTH IN PLWHA
}

\section{Health outcomes resulting from the quality of emotional expression in HIV/AIDS}

\section{patients}

Bénéfices liées à la santé résultants de la qualité de l'expression émotionnelle chez les personnes atteintes du VIH/SIDA

\author{
Nicole Cantisano
}

Université Toulouse-Jean Jaurès, URI Octogone-Cerpp, Toulouse, France

Bernard Rimé

Université de Louvain, Institut de Recherche en Sciences Psychologiques, Louvain-la-Neuve,

Belgium

Mohammad Hassan Afzali

Université Toulouse-Jean Jaurès, URI Octogone, Toulouse, France

María T. Muñoz-Sastre

Université de Toulouse Jean Jaurès, URI Octogone-Cerpp, Toulouse, France

Correspondence concerning this article should be addressed to Nicole Cantisano, URI OctogoneCerpp, Pavillon de la Recherche Bureau R39, Université Toulouse-Jean Jaurès, 5 allée Antonio Machado, Toulouse Cedex 9, 31058 France. Phone (+33)5-61-50-25-97. E-mail: cantisanonicole@gmail.com 


\title{
QUALITY OF SSE AND HEALTH IN PLWHA
}

\begin{abstract}
Introduction: Studies on emotional expression and its impact upon health have mainly focused on quantitative aspects of interactions rather than on their quality. Objective: The present study aimed to examine the interpersonal quality of interactions in the Social Sharing of Emotions (SSE) in People Living With HIV/AIDS (PLWHA), and its impact on patients' physical and psychological well-being. Method: 101 PLWHA answered a questionnaire (Likert-scale items) which assessed the following: shame, guilt, perceived stigma, perceived physical health, perceived mental health, SSE and the interpersonal quality of SSE (IQSSE). The main hypotheses were compiled into a theoretical model which was tested by a series of Structural Equation Modeling (SEM) analyses. Results: The final solution resulted into a well-fit model which showed that: (1) shame predicted IQSSE, (2) perceived stigma mediated the relationship between IQSSE and guilt, and (3) perceived Mental Health mediated the relationship between IQSSE and perceived Physical Health. Conclusion: These results corroborate previous findings which demonstrate that (1) IQSSE is independent from quantitative aspects of SSE and that (2) the way the SSE takes place is crucial to the benefits it induces.
\end{abstract}

Keywords: Social Sharing of Emotions (SSE); HIV/AIDS; mental health; physical health 


\section{QUALITY OF SSE AND HEALTH IN PLWHA}

\section{Résumé}

Introduction : Les études qui s'intéressent à l'expression émotionnelle et son impact sur la santé ciblent davantage des aspects quantitatifs des interactions et non pas des aspects qualitatifs de celles-ci. Objective : La présente étude a eu comme objectif d'examiner la perception de la qualité interpersonnelle des interactions lors du partage social des émotions (PSE) chez les personnes atteintes du VIH/SIDA, et son impact au niveau du bien-être physique et psychologique chez ces patients. Méthode : 101 patients atteints du VHI/SIDA ont répondu à un questionnaire (items likert) évaluant les variables suivantes: honte, culpabilité, stigmatisation perçue, santé physique perçue, santé mentale perçue, PSE et la perception de la qualité interpersonnelle du PSE. Les hypothèses principales ont été regroupées dans un modèle théorique qui a été testé par une série d'analyses des modélisations en équations structurales. Résultats : Au final, la solution qui a résulté dans un modèle bien ajusté a montré que : (1) la honte est un prédicteur de la perception de la qualité interpersonnelle du PSE, (2) la perception de la stigmatisation est une médiatrice de la relation entre la perception de la qualité interpersonnelle du PSE et la culpabilité, et (3) la santé mentale perçue a été une variable médiatrice entre la perception de la qualité interpersonnelle du PSE et la santé physique perçue. Conclusion : Ces résultats corroborent des études précédentes qui ont mis en avant que (1) la perception de la qualité interpersonnelle du PSE est indépendante des aspects quantitatifs de celui-ci et (2) la façon dont le PSE a lieu est cruciale pour les bénéfices dont celui-ci est porteur. Mots clés: Partage Social des Emotions (PSE); VIH/SIDA; santé mentale; santé physique 


\section{QUALITY OF SSE AND HEALTH IN PLWHA}

\section{Health Outcomes Resulting from the Quality of Emotional Expression in HIV/AIDS \\ Patients Living in the Dominican Republic}

When people experience emotions, they subsequently turn towards significant others to share and talk about their emotional experience (Rimé, 2009). This propensity to speak about emotional experiences was described as the Social Sharing of Emotions (SSE). Abundant data reveals that $80-95 \%$ of emotional experiences are socially shared (for review, Rimé, 2009), regardless of the strength and whatever the type of emotion experienced. However, episodes involving shame or guilt were exceptions linked to inhibited social sharing or emotional secrecy (Finkenauer \& Rimé, 1998). Significantly, talking about stressful experiences (e.g., chronic disease) in a suitable social environment is associated with enhanced psychological adaptation (Lepore, Ragan \& Jones, 2000).

People living with a chronic illness (e.g., chronic pain or cancer) may experience difficulties with the social sharing of disease-related emotions due to the perception of social constraints (Herbette \& Rimé, 2004; Lepore, Ragan \& Jones, 2000). This seems to be particularly the case of People Living with HIV/AIDS (PLWHA). Cantisano, Rimé and Munoz-Sastre (2013) observed PLWHA to report the same willingness to share their illness-related emotions as respondents living with cancer or diabetes. However, PLWHA differed considerably from the latter, demonstrating greater inhibition of actual sharing linked to their illness. Several factors could account for this difference characterizing PLWHA; for instance, feelings of shame and/or guilt are often associated with the illness experience (Landau \& York, 2004; Tangney \& Dearing, 2002). Furthermore, due to HIV-related stigma, these patients may perceive a particularly high level of social constraint in their social environment (Bos, Dijker \& Koomen, 2007). The question then arises of the consequences that this restricted emotional expression entails for PLWHA. 


\section{QUALITY OF SSE AND HEALTH IN PLWHA}

Findings reviewed so far lead to the conclusion that PLWHA patients manifest a deficit in the social sharing of their illness-related emotions, and that such deficits in emotional expression generally can lead to bio-psychosocial consequences (e.g. Petrie et al, 2004). Several authors (Kennedy-Moore \& Watson, 1999; Panagopoulou, Rimé, Maes \& Montgomery, 2006) have emphasized that empirical studies on effects of emotional expression were predominantly focused on SSE quantity (i.e., how much individuals share their feelings) rather than on SSE quality (i.e., the way that emotional expression takes place). In a study on anticipatory distress among patients awaiting heart surgery, Panagopoulou et al. (2006) demonstrated that SSE quality - and not SSE quantity — predicted reduced distress on the day before surgery. The importance of analyzing the quality of interactions during the SSE was also evidenced in the investigation of the links between emotional expression and reduced distress following an emotional episode. While previous studies failed to support such a link, Nils and Rimé (2012) found that the participants, who had benefitted from an addressee's cognitive reappraisal during the SSE, were the only ones reporting emotional recovery from the episode.

The present study aimed to examine the quality of SSE interactions in PLWHA, and its impact on these patients' perceived physical and psychological well-being. Given the differential impact of quality of social exchanges on psychological adjustment (e.g. Brooks \& DunkelSchetter, 2011), it is plausible to consider that the quality of emotional disclosure could be determinant when it comes to psychological adjustment in chronic illness such as HIV/AIDS. While taking into consideration the relationships between emotional expression and variables such as shame, guilt, HIV-related stigma, as well as the associations between emotional expression and perceived mental/physical health, a theoretical model was proposed (Fig.1).

First, this theoretical model links shame and guilt, in line with evidence-based theory (Tangney \& Dearing, 2002) manifesting important correlations between these two self-conscious 


\section{QUALITY OF SSE AND HEALTH IN PLWHA}

emotions. Second, in consistency with empirical evidence documenting shame and guilt to predict perceived HIV-related stigma (Landau \& York, 2004); the proposed model includes shame and guilt as predictors of perceived HIV-related stigma. Third, following abundant data demonstrating the association between perceived HIV-related stigma and self-disclosure in PLWHA (Derlega et al., 2002), perceived HIV-related stigma is expected to predict emotional expression. However, the model limits its predictions to the interpersonal quality of SSE (IQSSE) in accordance with Panagopoulou et al.'s (2006) findings where SSE quality but not quantity was linked to distress. Fourth, emotional expression, operationalized as IQSSE, is expected to predict PLWHA's perceived mental and physical health as a recognized consequence of emotional expression/inhibition upon individuals' health (Frattaroli, 2006; Petrie et al., 2004). This theoretical model (Fig.1) was tested using Structural Equation Modeling (SEM).

\section{Methods}

\section{Procedure}

Patients were sampled (purposive sampling) from two different health care institutions of the Dominican Republic's National HIV/AIDS health care program (DIGECITS). During patients' medical appointments, a doctor, nurse or other medical staff member informed patients about the study and proposed voluntary participation. The interviews' length (approximately one hour), content and confidentiality were explained while soliciting participation. If patients chose to volunteer, the researcher met with the patient following their medical appointment. Given high illiteracy rates, a written informed consent form was read and carefully explained to all participants. Consent was obtained through patients' signature of this form. A questionnaire (in Spanish) was administered in an interview modality to ensure comprehension.

\section{Participants}




\section{QUALITY OF SSE AND HEALTH IN PLWHA}

The present study was conducted in two HIV/AIDS care units in Santiago, Dominican

Republic's second most populated city. Data was collected during a two-month period (July $14^{\text {th }}$ to September $8^{\text {th }}$ 2011). While 109 outpatients were approached, a total of 101 PLWHA outpatients (50 females, 51 males and no transgender) under anti-retroviral (ARV) therapy agreed to participate in the study $(95.28 \%$ acceptance rate).

\section{Measures}

General information and illness history. Following questions relating to respondent's age, sex, level of education, professional occupation, and marital status, open-ended questions assessed time since diagnosis, time since the beginning of ARV therapy and infection mode. The last CD4+ cells count was obtained from medical records under patients' consent.

Current shame and guilt. The five shame items $(\alpha=0.72)$ and five guilt items $(\alpha=0.74)$ were used from the State Shame and Guilt Scale (Tangney \& Dearing, 2002), which were backtranslated from English to Spanish for the purpose of this study. Items were to be rated on a 5point Likert scale $(1=$ not at all; $5=$ extremely $)$. Higher scores indicate higher levels of shame and guilt respectively.

\section{Quality of life and physical symptoms specific to the HIV/AIDS experience. These} variables were assessed through the 35-item $(\alpha=0.91)$ Spanish validation (Peña de León et al., 2010) of the Medical Outcomes Study HIV Health Survey (MOS-HIV). Following recommendations from Revicki, Sorensen and Wu (1998), standardized perceived mental health and perceived physical health summary scores were calculated. First, scores were transformed into raw scale scores ranging from zero to 100 . Then, these raw scores were transformed into $z^{-}$ scores in order to be standardized to the Roche patient population (data from over 2,500 patients with HIV disease). Finally, the summary measures were transformed to have a mean of 50 and a 


\section{QUALITY OF SSE AND HEALTH IN PLWHA}

standard deviation of 10, thus obtaining a perceived Mental Health Score (MHS) and a perceived Physical Health Score (PHS). Higher scores correspond to better perceived health.

SSE linked to the illness (quantity). This variable was assessed through four items backtranslated from French (Rimé et al., 1991) to Spanish, and previously adapted to the illness context by Cantisano, Rimé \& Muñoz-Sastre (2013): (1) desire to share illness-related emotions ('During the past week, have you felt the desire to talk about your feelings and emotions related to your illness?'), (2) frequency of SSE during the previous week ('During the past week, how many times have you talked about your feelings and emotions related to your illness?'), (3) number of sharing partners during the previous week ('During the past week, with how many different people have you talked about your emotions and worries related to your illness?'), and (4) number of sharing partners during the previous month ('During the last month, with how many different people have you talked about your emotions and worries related to your illness?'). These four items were summed up into a total score $(\alpha=0.81)$, higher scores indicate a higher propensity to the SSE.

Perception of the interpersonal quality of SSE linked to the illness. The interpersonal subscale of the Quality of Sharing Inventory (Panagopoulou et al., 2006) was used to determine this variable. The nine items (e.g., 'The persons I share my thoughts and feelings with, understand exactly what I mean'; 'During the conversation I feel comfortable') in this scale $(\alpha=0.81)$ backtranslated from English to Spanish for the purpose of this study assessed respondents' perception of the appropriateness of the sharing listener, as well as of privacy and comfort of the sharing context (1=not at all; 5=extremely). Higher scores indicate an enhanced perception of the interpersonal quality of SSE. The Spanish translation of all nine items is displayed on the Appendix 1.

Perceived Stigma specific to HIV/AIDS. Using the Spanish validated abbreviated 21-items version of the HIV stigma Scale (Franke et al., 2010) (1=not at all; 5=extremely), an overall stigma 


\section{QUALITY OF SSE AND HEALTH IN PLWHA}

index (sum of all items) was calculated $(\alpha=0.91)$. Higher scores reflect a higher perception of HIV/AIDS related stigma.

\section{Statistical analysis}

The Theoretical Model presented in Figure 1 was tested through a series of SEM analyses conducted with the $20^{\text {th }}$ version of the AMOS computer program (Arbuckle, 2007). Before testing the model, gender differences were explored for all outcome variables. The only significant difference found $(F(1,99)=4.47 ; p<0.05)$ was for the MOS-HIV Mental Health Score (MHS), where male participants $(M=51.70 ; S D=8.45)$ reported higher scores than female participants $(M=47.97 ; S D=9.26)$. Given that this was the only significant difference, it was not considered necessary to conduct two separate models.

Five models were tested while evaluating the adequacy of each competing model through a number of "goodness-of-fit" statistics that are frequently used within the Confirmatory Factor Analysis (CFA), and that reflect the fit between the hypothesized statistical model and the actual data set (Bentler \& Bonett, 1980). Fit indices for each model are displayed in Table 2. Although the sample size may seem small for SEM, both the number of variables in the model (Bowen \& Guo, 2011), and the cohesion in the co-variance matrix legitimize the use of SEM in the case of the present study.

\section{Results}

\section{Socio-Demographic Characteristics}

Participants' mean age was $39.37(S D=11.40)$ years old (range $19-65)$. With respect to relationship status, $45.54 \%(n=46)$ of participants were single and $53.47 \%(n=55)$ of participants were in a legal union. As to the level of education, the highest level reached was assessed, and the sample's distribution was as follows: $3.96 \%(n=5)$ did not receive an education, $43.56 \%(n=44)$ of participants did not complete elementary school, $35.64 \%(n=36)$ 


\section{QUALITY OF SSE AND HEALTH IN PLWHA}

finished elementary school, 4.95\%\% $(n=5)$ had a high school diploma, 5.94\% $(n=6)$ had a technical degree and 5.94\% $(n=6)$ had a university degree. Concerning participants' professional occupation, the sample's distribution was as follows: $29.70 \%(n=30)$ were unemployed, $32.67 \%(n=33)$ had a full time job, $15.84 \%(n=16)$ had a part time job, $19.80 \%(n$ =20) were house makers, and one patient was on professional disability. Mean time since HIV diagnosis was $6.26(S D=5.00)$ years (range 2 months -22 years). The sample's mean CD4+ cells count was 387.73 cells $/ \mathrm{mm}^{3}(S D=242.83)$, assessed on average $4.88(S D=5.82)$ months before the study. Mean time since the start of ARV therapy was $3.83(S D=3.46)$ years (range 1 month -16 years). The reported modes of infection were heterosexual intercourse for $76.23 \%$ ( $n$ =77), unknown for $19.80 \%(n=20)$, other for $2.97 \%(n=3)$ and homosexual intercourse for $0.96 \%(n=1)$.

\section{Correlational analysis}

Means, standard deviations and inter-correlations of all measures are presented in Table 1. No significant correlation was found between SSE and IQSSE. SSE was not correlated with any other measure. IQSSE positively correlated with perceived PHS and MHS, and negatively correlated with shame, guilt and perceived stigma. Regarding the CD4+ cells count, one single significant correlation was found, that between CD4 + cells counts and perceived PHS.

\section{Structural equation modeling}

As to the first model (Fig. 1), all tested paths were significant with the exception of the guilt/IQSSE link. Therefore, this association was removed in a new model (Model 2a). As seen in Table 2, this second model showed that in the absence the guilt/IQSSE relation, guilt continued to have some indirect effect on IQSSE through perceived stigma $(\beta=-0.131 ; p \leq 0.001)$, but the relationship between shame and perceived stigma was found to be non-significant. In order to achieve a more parsimonious model, a new model (2b) was tested taking out the relationship 


\section{QUALITY OF SSE AND HEALTH IN PLWHA}

between shame and perceived stigma. The $X^{2} / d f$ ratio of model $2 \mathrm{~b}$ (see Table 2 ) showed that the model is indeed more parsimonious. However, modification indexes indicated that there was a strong relationship between the residual variances of perceived mental (MHS) and physical health (PHS) scores. This illustrates a relationship between perceived MHS and PHS that is not completely determined by IQSSE. Furthermore, modification indexes showed that there was a large part of the variance of perceived PHS that is determined by perceived MHS. As a consequence, a third model (3a; see table 2) was tested taking into account this relationship.

Model 3a showed that when the prediction of perceived PHS by perceived MHS is taken into consideration, the relation between QSI and perceived PHS was found to be non-significant. Thus, results show that perceived MHS completely mediates the relationship between IQSSE and perceived PHS. Therefore, in order to have a more precise final model, the prediction of perceived PHS by IQSSE was taken out, and a new model (3b) was tested. This final model (3b; see Table 2) showed the best fit and is the most efficiently effective, while no modifications were proposed. All tested relations were significant (Fig. 2).

\section{Discussion}

The present study expected to find the predictive value of shame, guilt and perceived stigma on HIV/AIDS patients' IQSSE, as well as the impact of the IQSSE on HIV/AIDS patients' perceived physical and psychological wellbeing. SEM analysis results support these expectations: results showed that shame, guilt and perceived stigma have a predictive value regarding the interpersonal quality of SSE, and the interpersonal quality of SSE has a predictive value with regards to perceived mental and physical health. However, the final solution differs from the hypothesized model in that shame is not linked to perceived stigma, and that the relationship between guilt and QSSE is fully mediated by perceived stigma. A plausible explanation for this unexpected finding is that while shame is linked to the perceived unworthy 


\section{QUALITY OF SSE AND HEALTH IN PLWHA}

self, guilt is linked to the perceived unworthy behavior (Tangney \& Dearing, 2002). Therefore, feelings of guilt concerning HIV-infection —in regards to one's own behavior involved in contamination and transmission—could be likely linked to perceived HIV-related stigma. Additionally, the final standardized solution demonstrates that the relationship between IQSSE and perceived physical health is fully mediated by perceived mental health scores. This finding was not explicitly hypothesized by the present study's theoretical model, yet one explanation might rely upon a methodological issue previously stressed by Revicki, Sorensen and Wu (1998): correlations between perceived MHS and PHS might compromise the independence of these two aspects of health-related quality of life in HIV/AIDS patients.

Given the sample size, result generalizations must be avoided. However, the present study's findings corroborate with Panagopoulou et al. (2006) demonstrating that the IQSSE is not linked at all to quantitative aspects of SSE. Furthermore, similar to patients anticipating cardiac surgery — where SSE quantity was not linked to preoperative distress - quantity of SSE was not associated at all to PLWHA's perceived physical and mental health scores. A recent experimental study (Nils \& Rimé, 2012)—which showed that, indeed, individuals' ways of sharing emotions along with listeners' responses (e.g., socio-affective or cognitive re-framing) is crucial to the type benefits induced by the SSE including emotional recovery-could clarify these important results pertaining to IQSSE. Further research should continue to focus on qualitative aspects of SSE when studying outcomes resulting from emotional expression.

One of the present study's limitations is the global assessment of IQSSE; specific members of the social network were not targeted. For example, in the case of cancer patients and perceived social support, Dakoff and Taylor (1990) demonstrated that support behaviors were found to be dependent on the source (e.g., particular actions can be perceived to be helpful by some but not all network members). Moreover, in an experimental study concerning breast 


\section{QUALITY OF SSE AND HEALTH IN PLWHA}

cancer patients and these patients' spouses, Manne et al. (2004) showed that partners' responses during illness-related self-disclosure play a key role when it came to patients' psychological distress. Future research should address this issue studying the perception of the quality of SSE in PLWHA with regards to spouses or close family members, as well as within a larger sample. Furthermore, another limitation that can be highlighted is the research bias linked to self-reported health measures; future studies should address these research questions while including objective health measures and experimental methodologies. Finally, the present study was conducted with a sample majorly composed by heterosexual participants $(99.04 \%)$. Yet, HIV infection is highly present among other populations such as men who have sex with men, sex workers or people who inject drugs (WHO \& Unaids, 2015). Thus, the present study's results are limited to a specific population, are not representative of the HIV/AIDS epidemic, and should not be generalized to other HIV/AIDS patient populations.

Practice and intervention implications can be drawn from the present study's findings. First, results concerning the predictive value of shame when it comes to the perception of the quality of SSE in PLWHA, could justify interventions focused on this self-conscious emotion as suggested by Dearing and Tangney (2011). Additionally, given the mediating role of perceived stigma (between guilt and emotional expression) in these patients, interventions focused on selfforgiveness specific to the HIV/AIDS experience (Temoshok \& Ward, 2005) would be relevant. Finally, due to the key role played by shame and guilt when it comes to emotional expression in these patients, interventions such as Greenberg's (2002) Emotion Focused Therapy would be pertinent in PLWHA's care. 


\section{QUALITY OF SSE AND HEALTH IN PLWHA}

\section{References}

Arbuckle, J.L. (2007). Amos16.0 User's Guide. Chicago, IL: SPSS Inc.

Bentler, P.M., Bonett, D.G., 1980. Significance tests and goodnessof fit in the analyses of covariance structures. Psychological Bulletin, 88, 588-606. DOI : 10.1037/00332909.88.3.588

Bos, A.E.R., Dijker, A. J. M., \&Koomen, W. (2007). Sex differences in emotional and behavioral responses to HIV+ individuals' expression of distress. Psychology \& Health, 22(4), 493511. DOI: $10.1080 / 14768320600976257$

Bowen, N. K., \&Guo, S. (2011). Structural equation modeling. Oxford University Press.

Brooks, K. P., \& Dunkel Schetter, C. (2011). Social negativity and health: Conceptual and measurement issues. Social and Personality Psychology Compass, 5(11), 904-918. DOI: 10.1111/j.1751-9004.2011.00395.x

Cantisano, N., Rimé, B., \& Muñoz-Sastre, M.T. (2013). The Social Sharing of Emotions in HIV/AIDS: A comparative study of HIV/AIDS, Diabetes and Cancer. Journal of Health Psychology, 18 (10), 1255-1267. DOI: 10.1177/135910531246243.

Dakof, G. A., \& Taylor, S. E. (1990). Victims' perceptions of social support: What is helpful from whom? Journal of personality and social psychology, 58 (1), 80. DOI : $10.1037 / 0022-3514.58 .1 .80$

Dearing, R. L., \& Tangney, J. P. E. (2011).Shame in the therapy hour.American Psychological Association.

Derlega , V.J., Winstead, B.A., Greene, K., Serovich, J., \& Elwood, W. (2002). Perceived HIVrelated Stigma and HIV Disclosure to Relationship Partners after Finding Out about the Seropositive Diagnosis. Journal of Health Psychology, 7(4), 415-432. DOI :

$10.1177 / 1359105302007004330$ 


\section{QUALITY OF SSE AND HEALTH IN PLWHA}

Finkenauer, C., \& Rimé, B. (1998). Socially shared emotional experiences vs. emotional experiences kept secret: Differential characteristics and consequences. Journal of Social and Clinical Psychology, 17, 295-318. DOI: 10.1521/jscp.1998.17.3.295

Franke, M.F., Muñoz, M., Finnegan, K., Zeladita, J., Sebastian, J.L., Bayona, J.N., \& Shin, S.S. (2010). Validation and Abbreviation of an HIV Stigma Scale in an Adult SpanishSpeaking Population in Urban Peru.Aids and Behavior, 14(1), 189-199. DOI: 10.1007/s 10461-008-9474-1

Frattaroli, J. (2006). Experimental disclosure and its moderators: A meta-analysis. Psychological Bulletin, 132, 823-865. DOI : 10.1037/0033-2909.132.6.823

Greenberg, L. S. (2002). Emotion-focused therapy: Coaching clients to work through their feelings. American Psychological Association.

Herbette, G. \& Rimé, B. (2004).Verbalization of emotion in chronic pain patients and their psychological adjustments.Journal of Health Psychology, 9, 661-676. DOI: $10.1177 / 1359105304045378$

Kennedy-Moore, E., \& Watson, J. C. (1999).Expressing emotions: Myths, realities, and therapeutic strategies. New York: Guilford Press.

Landau, G., \& York, A. (2004). Keeping and disclosing a secret among people with HIV in Israel. Health Social Work, 29, 116-126. DOI: 10.1093/hsw/29.2.116

Lepore, S.J., Ragan, J.D., \& Jones, S. (2000). Talking facilitates cognitive-emotional processes of adaptation to an acute stressor. Journal of Personality and Social Psychology, 78, 499-508. DOI : 10.1037/0022-3514.78.3.499

Manne, S., Sherman, M., Ross, S., Ostroff, J., Heyman, R. E., \& Fox, K. (2004). Couples' support-related communication, psychological distress, and relationship satisfaction 


\section{QUALITY OF SSE AND HEALTH IN PLWHA}

among women with early stage breast cancer. Journal of Consulting and Clinical Psychology, 72(4), 660. DOI : 10.1037/0022-006X.72.4.660

Nils, F., \& Rimé, B. (2012). Beyond the myth of venting: Social sharing modes determine emotional and social benefits from distress disclosure. European Journal of Social Psychology, 42(6), 672-681. DOI: 10.1002/ejsp.1880

Panagopoulou, E., Rime, B., Maes, S., \& Montgomery, A.J. (2006). Social Sharing of Emotion in Anticipation of Cardiac Surgery: Effects on Preoperative Distress. Journal of HealthPsychology, 11, 809-820. DOI : 10.1177/1359105306066644

Peña de León E., Aguilar Gaytán, S.S., Suárez Mendoza, A.A., \& Reyes Terán, G. (2007). Validación mexicana de la escala MOS-HIV de calidad de vida en pacientes infectados por el VIH. [Mexican Validation of the MOS-HIV quality of life scale in HIV-infected patients]. Revista Panamericana de Salud Publica, 21(5), 313-319.

Petrie, C., Fontanilla, I., Thomas, M.G., Booth, R.J. \& Pennebaker J.W. (2004). Effect of written emotional expression on immune function in patients with human immunodeficiency virus infection: a randomized trial. Psychosomatic Medicine, 66, 272-275. DOI: 10.1097/01.psy.0000116782.49850.d3

Revicki, D.A., Sorensen, S., \& Wu, A.W. (1998). Reliability and validity of physical health and mental health summary scores from the MOS HIV Health. Survey.Medical Care, 36(2), 126-137. DOI: 10.1097/00005650-199802000-00003

Rimé, B. (2009). Emotion Elicits the Social Sharing of Emotion: Theory and Empirical Review. Emotion Review, 1(1), 60-85. DOI: 10.1177/1754073908097189

Rimé, B., Mesquita, B., Philippot, P., \& Boca, S. (1991). Beyond the emotional event: Six studies on the social sharing of emotion. Cognition and Emotion, 5, 435-465. DOI: $10.1080 / 02699939108411052$ 


\section{QUALITY OF SSE AND HEALTH IN PLWHA}

Temoshok, L. \& Wald, R. (2005).Forgiveness and health in persons living with HIV/AIDS. In E.L. Worthington (Ed).Handbook of Forgiveness (pp. 335-348). New York: BrunnerRoutledge.

Tangney, J.P. \& Dearing, R.L. (2002). Shame and Guilt, New York, Guilford Press.

World Health Organisation (WHO) \& Unaids (2015). Global AIDS response progress reporting 2015. Geneva: WHO Press. 


\section{QUALITY OF SSE AND HEALTH IN PLWHA}

Table 1

Means, standard deviations, and inter-correlations (Pearson's r) of measures included in the study

$\begin{array}{lllllllll}M & 1 & 2 & 3 & 4 & 5 & 6 & 7 & 8\end{array}$

$(S D)$

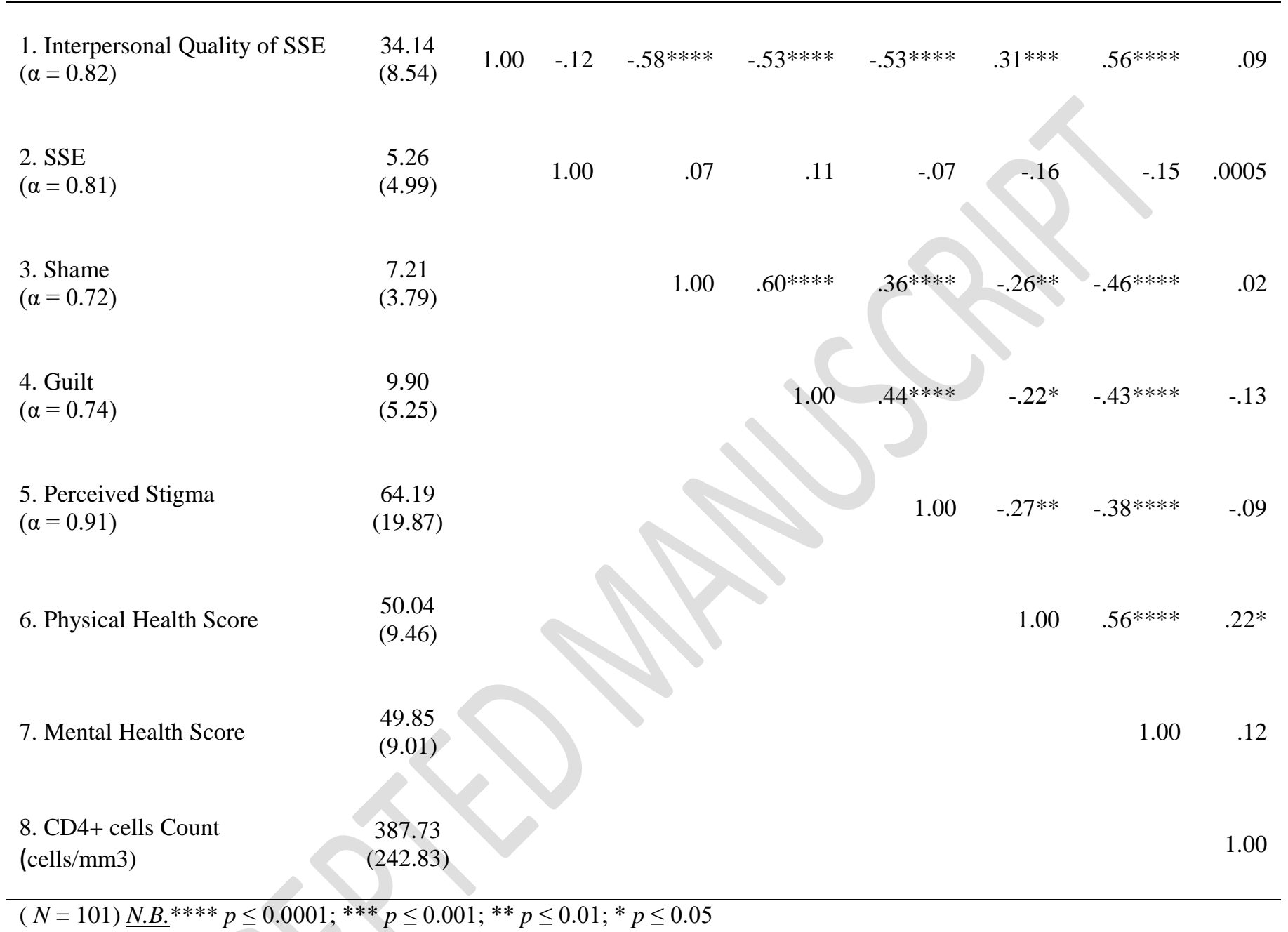




\section{QUALITY OF SSE AND HEALTH IN PLWHA}

Table 2

Fit indices for proposed models

\begin{tabular}{llllllll}
\hline Model & $\boldsymbol{d} \boldsymbol{f}$ & $\boldsymbol{X}^{2}$ & $\boldsymbol{X}^{2} / \boldsymbol{d} \boldsymbol{f}$ & RMSEA & NFI & CFI & Significance \\
\hline $\mathbf{1}$ & 7 & 34.752 & 4.965 & 0.199 & 0.839 & 0.861 & $p=0.0001$ \\
$\mathbf{2 a}$ & 8 & 38.265 & 4.783 & .195 & 0.822 & 0.849 & $p=0.0001$ \\
$\mathbf{2 b}$ & 9 & 40.151 & 4.46 & 0.186 & 0.813 & 0.844 & $p=0.0001$ \\
3a & 8 & 12.756 & 1.595 & 0.077 & 0.941 & 0.976 & $p=0.121$ \\
3b & 9 & 12.763 & 1.418 & 0.065 & 0.941 & 0.981 & $p=0.174$ \\
\hline
\end{tabular}

$\underline{N . B . R M S E A}=$ root mean squared error of approximation; NFI = Bentler-Bonett normed fit index; $\mathrm{CFI}=$ comparative fit index 


\section{QUALITY OF SSE AND HEALTH IN PLWHA}

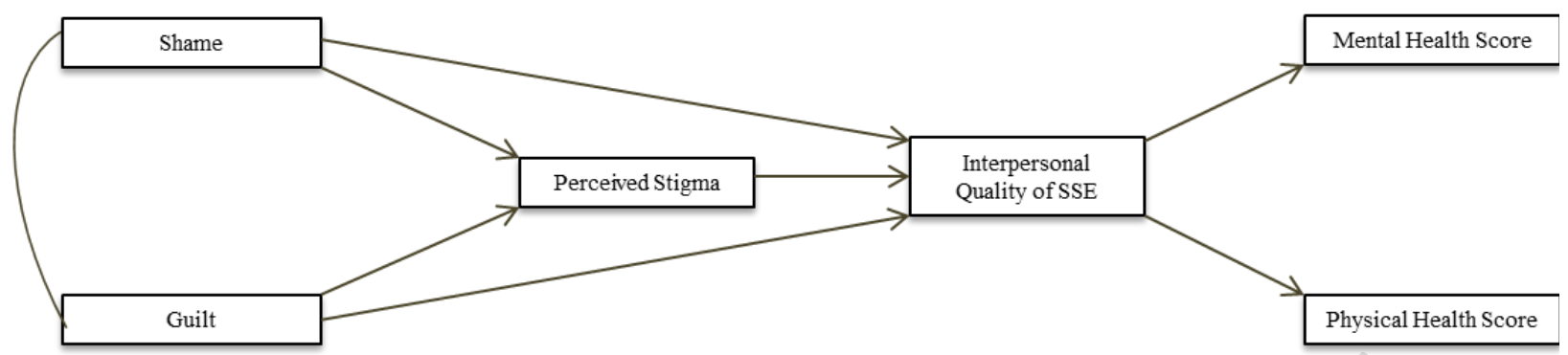

Figure 1 : Theoretical Model 


\section{QUALITY OF SSE AND HEALTH IN PLWHA}

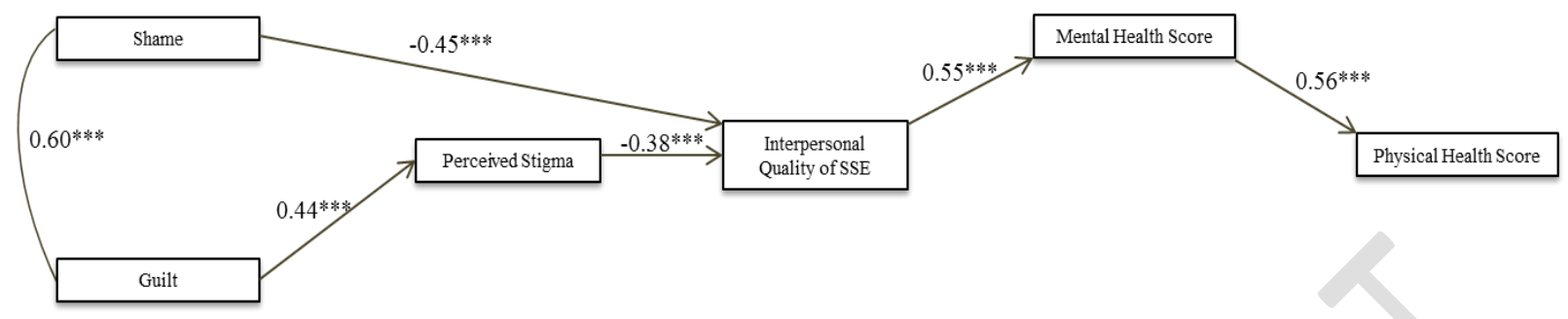

Figure 2 : Standardized solution for the final observed model $\underline{N . B .}$

$N=101$; Only significant paths are shown in the figure; $* * * p \leq 0.001$ 


\section{QUALITY OF SSE AND HEALTH IN PLWHA}

\section{Appendix 1.}

Spanish Translation of the Quality of Sharing Inventory items (interpersonal dimension)

Instrucciones: Las siguientes frases se refieren a los momentos en los cuales usted suele hablar de sus pensamientos y emociones relacionados a su enfermedad. Por favor indique en qué medida (1-5) suele sucederle lo que describimos.

1. Cuando comparto con otros mis pensamientos y sentimientos yo siento que las personas no me entienden y me malinterpretan *

2. Durante las conversaciones que tengo me siento cómodo/a

3. Las personas con las que comparto mis pensamientos y sentimientos entienden exactamente lo que yo quiero decir

4. Cuando hablo con las otras personas siento que hay una distancia entre nosotros*

5. Durante las conversaciones hay muchas discusiones con desacuerdos

6. Cada vez que hablo sobre mis pensamientos y sentimientos Las otras personas siempre me dicen lo mismo*

7. Cuando hablo de mis pensamientos y sentimientos, siento que las otras personas se llevan una idea equivocada de lo que soy

8. Durante las conversaciones que tengo me encuentro en una posición incómoda, como si no supiera que decir*

9. Yo hubiese preferido compartir mis pensamientos y sentimientos con otras personas, distintas a esas con las que comparto ahora

*Items to be reverse coded. 